\title{
Anti-lipase and antioxidant properties of 30 medicinal plants used in Oaxaca, México
}

\author{
Nemesio Villa-Ruano ${ }^{*}$, Guilibaldo G. Zurita-Vásquez ${ }^{1}$, Yesenia Pacheco-Hernández², Martha G. Betancourt- \\ Jiménez ${ }^{3}$, Ramiro Cruz-Durán ${ }^{4}$ and Horacio Duque-Bautista ${ }^{1}$ \\ ${ }^{1}$ Universidad de la Sierra Sur, Guillermo Rojas Mijangos S/N, Ciudad Universitaria, CP70800, Miahuatlán de Porfirio Díaz, Oaxaca, México.
${ }^{2}$ Instituto Tecnológico de Sonora, 5 de Febrero 818 Sur, Col. Centro, CP 8500, Ciudad Obregón, Sonora, México.
${ }^{3}$ Centro de Investigación y de Estudios Avanzados del IPN, Unidad Irapuato. Km 9.6 Libramiento Norte, Carretera Irapuato-León, CP 36000 , Irapuato México.
${ }^{4}$ Facultad de Ciencias UNAM, Ciudad Universitaria, México DF, Ciudad Universitaria, CP 04510, Del. Coyoacán, México, D.F.
}

\begin{abstract}
We report the results of in vitro anti-lipase and antioxidant assays using crude ethanolic extracts from 30 plants grown in Oaxaca, México. Anti-lipase tests were performed by using porcine pancreatic lipase (PPL) [EC 3.1.1.3] from Affymetrix/USB. The extracts of Solanum erianthum, Salvia microphylla, Brungmansia suaveolens and Cuphea aequipetala showed up to 60\% PPL inhibition. The effect of these extracts on the kinetic parameters of PPL $\left(\mathrm{K}_{\mathrm{m}}=0.36 \mathrm{mM}\right.$, and $\left.\mathrm{V}_{\max }=0.085 \mathrm{mM} \mathrm{min}^{-1}\right)$ revealed that the alcoholic preparations of $S$. erianthum and C. aequipetala engendered a non-competitive inhibition $\left(\mathrm{V}_{\max }^{\max }=0.055 \mathrm{mM} \mathrm{min}^{-1} ; \mathrm{V}_{\max }=0.053 \mathrm{mM} \mathrm{min}^{-1}\right)$, whereas those of $S$. microphylla and B. suaveolens produced a mixed inhibition $\left(\mathrm{K}_{\mathrm{m}}=0.567 \mathrm{mM}, \mathrm{V}_{\max }=0.051 \mathrm{mM} \mathrm{min}{ }^{-1} ; \mathrm{K}_{\mathrm{m}}=0.643 \mathrm{mM}, \mathrm{V}_{\max }=0.042 \mathrm{mM} \mathrm{min}^{-1}\right)$. In addition to these findings, seven extracts from different plants were able to inhibit PPL in the range of 30-50\%. Antioxidant tests against 2,2-Diphenyl-1-picryl hydrazyl (DPPH) confirmed that Arctostaphylos pungens, Gnaphalium roseum, Crotalaria pumila, Cuphea aequipetala, Rhus chondroloma, and Satureja laevigata possess relevant antioxidant activity $\left(\mathrm{IC}_{50}=50-80 \mu \mathrm{g} \mathrm{mL}-1\right)$. The general composition of the most effective ethanolic extracts was obtained in order to confirm their known chemistry reported by previous works. Comprehensive chemical analysis of the ethanolic extracts and their poisoning effects suggests that S. microphylla, C. aequipetala and A. pungens could be considered as the best sources with both desired properties.
\end{abstract}

Key terms: Phytotherapy, anti-obesity, antioxidant, Oaxacan ethnobotany.

\section{INTRODUCTION}

High prevalence illnesses such as diabetes mellitus, cancer and neurodegenerative diseases are induced by oxidative stress and obesity. These physiological disorders are commonly associated with improper diets and sedentary lifestyle. Current statistical studies demonstrate an alarming increase in obesity and neurodegenerative diseases in the past five years in Mexico (Rojas-Martínez et al., 2012). This fact has turned into a serious health problem that requires special attention. Scientific evidence suggests that neurological disorders, respiratory diseases and premature ageing are the result of continuous oxidative stress which is aggravated by alcoholism, depression, intensive work, smoking and being overweight (Reuter et al., 2010). Being overweight or obese should be prevented with constant exercise and dietary routines. Nevertheless when the latter techniques fail in obtaining $10 \%$ weight loss, pharmacological treatment is required. Despite the fact that this alternative is highly recommended, there are controversial results on the use of some pharmacological agents such as sibutramine (Villa-Ruano et al., 2011). Synthetic derivatives of lipstatin that inhibit triglyceride hydrolysis are strongly recommended for controlling weight disorders. Unfortunately, Orlistat ${ }^{\circledR}$ and related competitive inhibitors have side effects; however, they are relatively less aggressive compared with those of sibutramine. To date, the pharmaceutical market is limited to a short list of anti-obesity drugs. As a consequence of the need for new and more efficient anti-lipase agents, exhaustive plant screenings from Asiatic, African and European ethnobotanical sources have been performed (Birari and Bhutani 2007; Ekanem et al., 2007; Slanc et al., 2009; Gholamhoseinian et al., 2010; Zheng et al., 2010). Nonetheless, there is no information about the efficacy of Latin American medicinal plants on this topic. Mexico is a privileged country in possessing extensive information about the use and therapeutic properties of many plants. Within México, Oaxaca is considered one of the most biodiverse and multicultural states, but also highly marginalized (Caballero et al., 2004). Currently, people from rural communities of this state still depend on traditional folk medicine to cure their illnesses. In these places, the latter alternative is in many cases more accepted than allopathic medicine by native people. Here we report the results of in vitro anti-lipase and antioxidant assays using ethanolic extracts from plants of Oaxacan ethnomedicine in order to reveal some species with potential use in preventing obesity and cellular oxidative stress.

\section{METHODS}

Source of plants

The plant material was collected in San Andres Paxtlán, Oaxaca, México (16¹3.081' N 096³0.331’ W; 1996 m elevation) in April 2012 (Spring 2012). The identity of 30 species was corroborated at the Herbarium of the FCME-UNAM México, or by dichotomous keys (Martinez, 1979; Calderón y Rzedowski, 
2005). $50 \mathrm{~g}$ of distinct plant organs (Table I) were excised and immediately extracted with $100 \mathrm{~mL}$ of absolute ethanol for 15 days at room temperature in darkness. The crude extracts were filtered with Ahlstrom grade 642 filter paper and concentrated using a Buchi R-200 rotovaporator to approximately $10 \mathrm{~mL}$. These preparations were completely dried in a centrifuge concentrator (RVC 2-25 CD) for $3 \mathrm{~h}$. The resultant powder was stored in amber glass flasks at $4{ }^{\circ} \mathrm{C}$ until used. $3 \%$ DMSO was employed for resuspending the powder and to prepare different stocks (this solution did not show anti-lipase activity by itself).

TABLE I

Anti-lipase and antioxidant activities of 30 plants from Oaxacan ethnnomedicine.

\begin{tabular}{|c|c|c|c|c|c|}
\hline & Scientific name & Family & Organs ${ }^{*}$ & LI $(\%) \mathbb{I}$ & AA $\left(\right.$ IC50 $\left.\mu \mathrm{g} \mathrm{mL}^{-1}\right)$ \\
\hline 1 & Chyrsanthemum parthenium (L.) Sch. Bip. & Asteraceae & Shoots and leaves & $5.7 \pm 2.3^{\S}$ a & $125.1 \pm 8.5^{\S g}$ \\
\hline 2 & Gnaphalium roseumKunth. & Asteraceae & Shoots and leaves & $6.3 \pm 0.5^{\mathrm{a}}$ & $72.9 \pm 3.2^{\mathrm{b}}$ \\
\hline 3 & Baccharis salicifolia (Ruiz et Pav.) Pers.Lis & Asteraceae & Shoots and leaves & $6.6 \pm 0.9^{a}$ & $154.4 \pm 6.0^{\mathrm{i}}$ \\
\hline 4 & Heimia salicifolia Link. & Lythraceae & Shoots and leaves & $7.6 \pm 0.2^{\mathrm{a}}$ & $245.3 \pm 11.3^{\mathrm{m}}$ \\
\hline 5 & Borago officinalis L. & Boraginaceae & Shoots, leaves and flowers & $9.3 \pm 0.5^{\mathrm{b}}$ & $115.23 \pm 3.4^{\mathrm{f}}$ \\
\hline 6 & Passiflora ligularis Juss. & Passifloraceae & Leaves and tendrils & $9.3 \pm 0.4^{b}$ & $386.8 \pm 12.7^{\mathrm{r}}$ \\
\hline 7 & Montanoa tomentosa (Cerv.) & Asteraceae & Shoots and leaves & $10.2 \pm 0.4^{\mathrm{b}}$ & $356.2 \pm 13.2^{q}$ \\
\hline 8 & Crotalaria pumila Ort. & Fabaceae & Shoots and leaves & $12.0 \pm 0.3^{b}$ & $75.3 \pm 2.8^{\mathrm{b}}$ \\
\hline 9 & Lippia alba (Mill.) N.E. Br. & Verbenaceae & Shoots and leaves & $12.4 \pm 1.1^{\mathrm{b}}$ & $89.6 \pm 2.4^{\mathrm{d}}$ \\
\hline 10 & Marrubium vulgare $\mathrm{L}$. & Laminaceae & Shoots and leaves & $13.2 \pm 0.6^{\mathrm{b}}$ & $102.6 \pm 3.5^{\mathrm{e}}$ \\
\hline 11 & Diphysa floribunda Peyr. & Fabaceae & Shoots, leaves and flowers & $15.3 \pm 0.7^{c}$ & $289.3 \pm 13.1^{\circ}$ \\
\hline 12 & Anrendera cordifolia (Ten.) Steenis & Basellaceae & Leaves and aerial tubers & $18.6 \pm 2.0^{\mathrm{d}}$ & $223.7 \pm 19.2^{1}$ \\
\hline 13 & Montanoa hibiscifolia Benth. & Asteraceae & Shoots and leaves & $19.7 \pm 1.5^{\mathrm{d}}$ & $87.2 \pm 3.4^{\mathrm{d}}$ \\
\hline 14 & Physalis philadelphica Lam. & Solanaceae & Shoots, leaves and flowers & $22.6 \pm 1.8^{\mathrm{e}}$ & $209.5 \pm 3.5^{j}$ \\
\hline 15 & Artemisia ludoviciana Nutt. & Asteraceae & Shoots and leaves & $23.4 \pm 2.2^{\mathrm{e}}$ & $215.6 \pm 11.5^{\mathrm{k}}$ \\
\hline 16 & Ipomoea wolcottiana Rose & Convolvulaceae & Shoots and leaves & $26.5 \pm 2.4^{\mathrm{f}}$ & $445.8 \pm 5.9^{\mathrm{s}}$ \\
\hline 17 & Satureja laevigata Standl. & Laminaceae & Shoots and leaves & $28.5 \pm 1.3^{f}$ & $85.4 \pm 2.5^{\mathrm{d}}$ \\
\hline 18 & Microsechium helleri (Peyr.) Cogn. & Cucurbitaceae & Tuberous roots and axillary buds & $32.8 \pm 1.5^{\mathrm{g}}$ & $256.3 \pm 4.5^{\mathrm{n}}$ \\
\hline 19 & Loeselia mexicana (Lam.) Brand. & Polemoniaceae & Shoots and leaves & $35.2 \pm 2.5^{g}$ & $468.4 \pm 23.8^{\mathrm{t}}$ \\
\hline 20 & Sambucus mexicana Presl. & Caprifoliaceae & Shoots and leaves & $37.1 \pm 2.1^{\mathrm{g}}$ & $135.1 \pm 4.1^{\mathrm{h}}$ \\
\hline 21 & Chiranthodendron pentadactylon Larreat & Malvaceae & Shoots and leaves & $39.9 \pm 2.5^{g}$ & $102.6 \pm 6.6^{\mathrm{e}}$ \\
\hline 22 & Phaseolus coccineus L. & Fabaceae & Shoots, leaves and flowers & $41.3 \pm 0.4^{\mathrm{g}}$ & $256.4 \pm 12.5^{\mathrm{n}}$ \\
\hline 23 & Cestrum anagyris Dunal & Solanaceae & Shoots and leaves & $45.6 \pm 0.6^{\mathrm{h}}$ & $132.8 \pm 4.3^{\mathrm{h}}$ \\
\hline 24 & Rhus chondroloma Standl. & Anacardiaceae & Shoots, leaves, flowers and fruits & $49.4 \pm 1.4^{\mathrm{i}}$ & $78.6 \pm 1.1^{\mathrm{c}}$ \\
\hline 25 & Arctostaphylos pungens Kunt & Ericaceae & Shoots, leaves and stem bark & $53.4 \pm 2.1^{\mathrm{i}}$ & $56.4 \pm 3.3^{\mathrm{a}}$ \\
\hline 26 & Salmea scandens (L.) D.C. & Asteraceae & Stem bark and leaves & $55.9 \pm 0.9^{\mathrm{i}}$ & $344.5 \pm 17.8^{p}$ \\
\hline 27 & Cuphea aequipetala Cav. & Lythraceae & Shoots and leaves & $60.5 \pm 0.2^{j}$ & $76.5 \pm 2.3^{\mathrm{b}}$ \\
\hline 28 & $\begin{array}{l}\text { Brungmansia suaveolens (Humb. et Bonpl.) } \\
\text { Berch et Presl. }\end{array}$ & Solanaceae & Flowers & $65.3 \pm 2.7^{\mathrm{k}}$ & $356.1 \pm 5.6^{\mathrm{q}}$ \\
\hline 29 & Salvia microphylla Kunth & Laminaceae & Shoots and leaves & $67.1 \pm 0.3^{\mathrm{k}}$ & $99.2 \pm 1.1^{\mathrm{e}}$ \\
\hline 30 & Solanum erianthum D. Don. & Solanaceae & Shoots, leaves and flowers & $67.8 \pm 3.2^{\mathrm{k}}$ & $104.8 \pm 3.4^{\mathrm{e}}$ \\
\hline $31^{*}$ & Orlistat & & & $97.6 \pm 0.4^{1}$ & \\
\hline $32^{*}$ & BHT & & & & $8.3 \pm 0.01^{\mathrm{u}}$ \\
\hline $33^{*}$ & Ascorbic Acid & & & & $4.2 \pm 0.03^{\mathrm{v}}$ \\
\hline
\end{tabular}

* Mix of plant organs; $§$ Means with standard deviation from experiments performed in quintuplicate. LI, \% of lipase inhibition; $\mathrm{AA}$, antioxidant activity expressed in IC ${ }_{50}$. ${ }^{\natural}$ The percentage of PPL inhibition corresponds to the results of using $100 \mu \mathrm{g} \mathrm{mL} \mathrm{L}^{-1}$ from each extract. Means with different letters are statistically different according to an ANOVA-Tukey Test $(p<0.05)$. 
Anti-lipase activity

The turbidimetric method proposed by Shihabi and Bishop (1971) was used to determine the triolein hydrolysis under controlled conditions. The preparation of triolein emulsion was achieved as described by the same authors. Porcine pancreatic lipase (PPL) [EC 3.1.1.3] was purchased from Affymetrix/ USB and adjusted to a final concentration of $250 \mu \mathrm{g} \mathrm{mL}^{-1}(\sim 6$

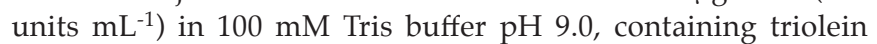
$(0.3 \mathrm{mM})$ sodium deoxycholate $(20 \mathrm{mM})$, colipase $\left(3 \mathrm{mg} \mathrm{L}^{-1}\right)$ and calcium chloride $(0.02 \mathrm{mM})$. Enzymatic reactions had a final volume of $1 \mathrm{~mL}$ and were initiated by its incubation at 37 ${ }^{\circ} \mathrm{C}$ for $30 \mathrm{~min}$ with two different concentrations of ethanolic extracts (50 and $100 \mu \mathrm{g} \mathrm{mL}-1$ ). Changes in turbidity were measured at $340 \mathrm{~nm}$ by spectrophotometry (Beckman DU 7400). The percentage of inhibition was calculated according to Gholamhoseinian et al., (2010) as a semi-quantitative parameter to estimate the effectiveness of each extract. Orlistat (B) (Medimart Labs) was employed as the reference standard of inhibition. Kinetic parameters of PPL were determined by saturation curves using triolein as a substrate $(0.2,0.4,0.8$, 1.6, 2.0 and $2.2 \mathrm{mM}$ ) and adjusted by non-linear regression using the Solver ${ }^{\circledR}$ software as described by Villa-Ruano et al. (2009). The specific inhibitory effect of ethanolic extracts on PPL kinetics was determined from different substrate concentrations $(0.2-2.2 \mathrm{mM})$ and two extract concentrations (50 and $100 \mu \mathrm{g} \mathrm{mL}^{-1}$ ). Double-reciprocal Lineweaver-Burk plot regressions were performed with SigmaPlot 10.0 (Systat Software, Inc). All the experiments were assayed in quintuplicate.

Antioxidant activity

Antioxidant activity was determined according to Shafaghat et al. (2011), using butylated hydroxytoluene (BHT, SigmaAldrich Co.) and vitamin C (Sigma-Aldrich Co.) as reference standards. 2,2-Diphenyl-1-picryl hydrazyl (DPPH) was also obtained from Sigma-Aldrich Co. Dose-response curves (20-500 $\mu \mathrm{g} \mathrm{mL}{ }^{-1}$ ) were performed for each extract in order to obtain the respective half maximum inhibitory concentration $\left(\mathrm{IC}_{50}\right)$. All the experiments were performed in quintuplicate.

\section{Comparative phytochemical screening}

To obtain the general chemical composition of the most effective plant extracts in both biological activities (22), a comparative phytochemical screening was performed. These extracts were directly processed to determine flavonoids, tannin/phenols, terpenes, steroids, saponins, alkaloids and cardiac glycosides according to general methods developed by Harborne (1998) and Háuad-Marroquín (2010). Semiquantitative content was estimated for some metabolites in order to get an approach to their abundance in ethanolic extracts. Flavonoid content was determined at $450 \mathrm{~nm}$ by calibration curves using quercetin as a flavonoid standard. Total tannin/phenolic content was determined using gallic acid as internal standard and using the reagent of FolinCiocalteau $(750 \mathrm{~nm})$ according to Nugroho et al. (2013). Alkaloid content was calculated with Dragendorff's reagent at $435 \mathrm{~nm}$ according to Villa-Ruano et al. (2012). Total saponin content was determined at $408 \mathrm{~nm}$ considering digitonin as reference standard. Cardiac glycosides were determined at
$486 \mathrm{~nm}$ based on their reaction with picric acid in alkaline media using digitoxine as reference standard (Solich et al, 1992). Results were expressed as abundant for the case of $\geq 500$ $\mu \mathrm{g} \mathrm{gFW}^{-1}$ (fresh weight), low for 50-400 $\mu \mathrm{g} \mathrm{gFW}^{-1}$ or absent (undetectable). Terpene and steroid determination was only qualitative. All the reference standards were obtained from Sigma-Aldrich Co. and the experiments were performed in triplicate.

\section{Statistical analysis}

The anti-lipase and antioxidant data were processed by an ANOVA coupled to a Tukey Test $(\mathrm{p}<0.05)$ using SigmaPlot 10.0 software. All results were expressed as mean \pm standard deviation $(n=5)$. In order to compare the two biological parameters, the results were plotted in a stacked bar graph.

\section{RESULTS}

Table I summarizes the results of antioxidant and anti-lipase assays using ethanolic extracts from 30 medicinal plants commonly grown in family plots in rural communities of Oaxaca's Southern Lowlands. These medicinal plants are orally or topically administered to treat diverse diseases. Crude ethanolic extracts from Solanum erianthum, Salvia microphylla, Brungmansia suaveolens and Cuphea aequipetala, were the most effective, showing up to $60 \%$ but less than $70 \%$ inhibition on PPL. On the other hand, Salmea scandens, Arctostaphylos pungens, Rhus chondroloma, Cestrum anagyris, Phaseolus coccineus, Chiranthodendron pentadactylon and Sambucus mexicana showed a range inhibition of $40-56 \%$. The latter extracts never achieved the characteristic in vitro inhibition of Orlistat ${ }^{\circledR}(>90 \%)$, but showed a strong inhibitory effect on the activity of PPL. Results of the antioxidant screening reveal that the ethanolic extract of $A$. pungens was the best for the stability of DPPH radical $\left(\mathrm{IC}_{50}=56.4 \mu \mathrm{g} \mathrm{mL}{ }^{-1}\right)$. Other alcoholic extracts from Gnaphalium roseum, Crotalaria pumila, Cuphea aequipetala, Rhus chondroloma and Satureja laevigata had a high antioxidant activity against the $\mathrm{DPPH}$ radical $\left(\mathrm{IC}_{50}=73-85 \mu \mathrm{g}\right.$ $\mathrm{mL}^{-1}$ ) but only some of these species showed significant antilipase activity $(>40 \%)$. Figure 1 shows that anti-lipase activity is not necessarily associated with antioxidant activity, but there were interesting coincidences for the case of S. erianthum, C. aequipetala and $A$. pungens. According to our results, Lippia alba, Crotalaria pumila, Marrubium vulgare and Chrysanthemum parthenium could be considered as alternatives to antioxidants, but not as anti-lipase sources (Figure 1). The ANOVA coupled to a Tukey test revealed significant differences among the effectiveness of ethanolic extracts $(p<0.05)$ in the two biological activities (Table I). The comparative phytochemical screening of the most relevant extracts (22) showed diverse components dissolved in each ethanolic preparation (Table II). Nevertheless, the presence and high abundance of flavonoids and/or phenolic compounds was evident in all the samples. Alkaloid content was abundant mainly for S. eriathum, B. suaveolens, Ipomoea wolcottiana and S. scandens. Terpenes, saponins and steroids were present in almost all the ethanolic extracts but only the samples of $S$. erianthum, $R$. chondroloma S. mexicana and C. pumila gave positive results for cardiac glycosides.

The effect of the four most effective plant extracts on kinetic parameters of PPL is shown in Table III. Under our laboratory 
conditions, the $\mathrm{K}_{\mathrm{m}}$ value of triolein for this enzyme was 0.36 $\mathrm{mM}$ and $\mathrm{V}_{\max }$ was $0.085 \mathrm{mM} \mathrm{min}^{-1}$ (Table III). Lineweaver-Burk plot analysis performed for the S. erianthum extract showed a non-competitive inhibition where only $\mathrm{V}_{\max }$ was significantly decreased by both assayed concentrations (Fig. 2, Table III). The S. microphylla extract revealed a mixed inhibition on PPL (Fig. 3, Table III). Similar results were obtained for the alcoholic extract of flowers from B. suaveolens (Fig. 4, Table III). The effect of these extracts was clearly reflected in the modification of the $\mathrm{K}_{\mathrm{m}}$ and $\mathrm{V}_{\max }$ values (Table III). The corresponding extract of $C$. aequipetala had a non-competitive effect on kinetics of PPL, like S. erianthum (Figure 5, Table III).

\section{DISCUSSION}

According to our results, the kinetic parameters of PPL (Affymetrix/USB) were as follows: $\mathrm{K}_{\mathrm{m}}=0.36 \mathrm{mM}$ and $\mathrm{V}_{\max }=$ $0.085 \mathrm{mM} \mathrm{min}^{-1}$. The absolute values of these parameters are

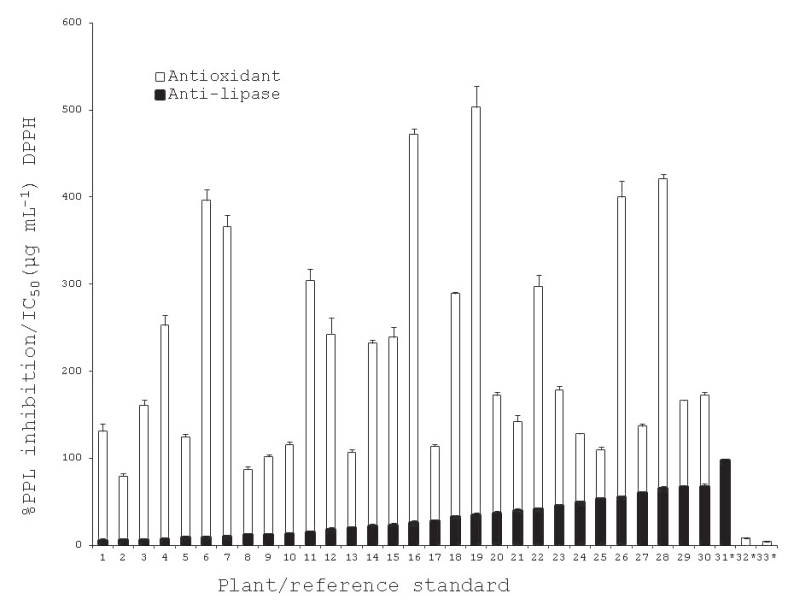

Figure 1. Effect of 30 ethanolic extracts on PPL activity and DPPH stability. Numbers correspond to the order of Table I. Number with asterisks indicate the reference standards used to normalize both biological activities. Bars represent the standard deviation from five repetitions.

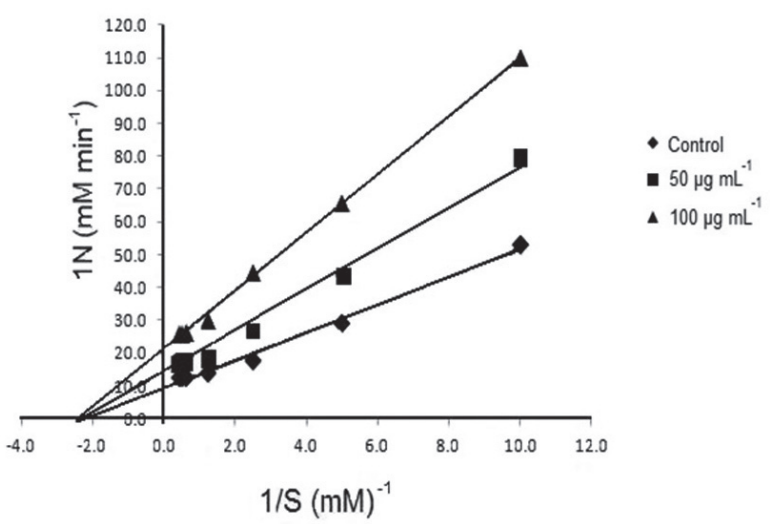

Figure 2. Lineweaver-Burk plot analysis for PPL at two concentrations of the ethanolic extract from Solanum eriathum (50 and $100 \mu \mathrm{g} \mathrm{mL}^{-1}$ ), using different triolein concentrations (0.2$2.2 \mathrm{mM})$.

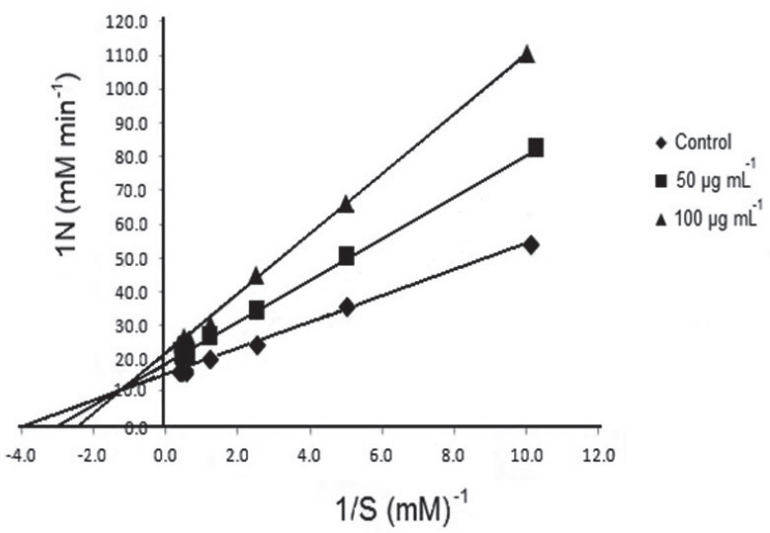

Figure 3. Lineweaver-Burk plot analysis for PPL at two concentrations of the ethanolic extract from Salvia microphylla (50 and $\left.100 \mu \mathrm{g} \mathrm{mL}^{-1}\right)$, using different triolein concentrations (0.2-2.2 $\mathrm{mM})$.

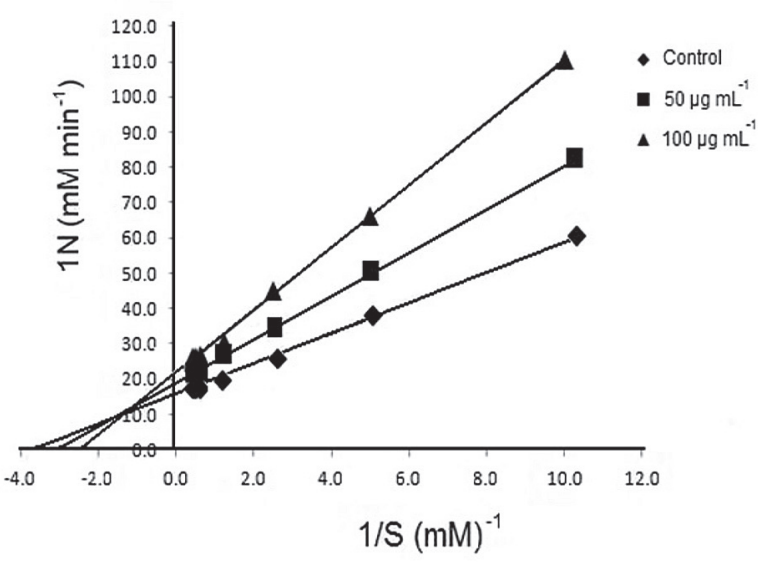

Figure 4. Lineweaver-Burk plot analysis for PPL at two concentrations of the ethanolic extract from Brungmansia suaveolens (50 and $100 \mu \mathrm{g} \mathrm{mL}^{-1}$ ), using different triolein concentrations (0.2-2.2 $\mathrm{mM})$.

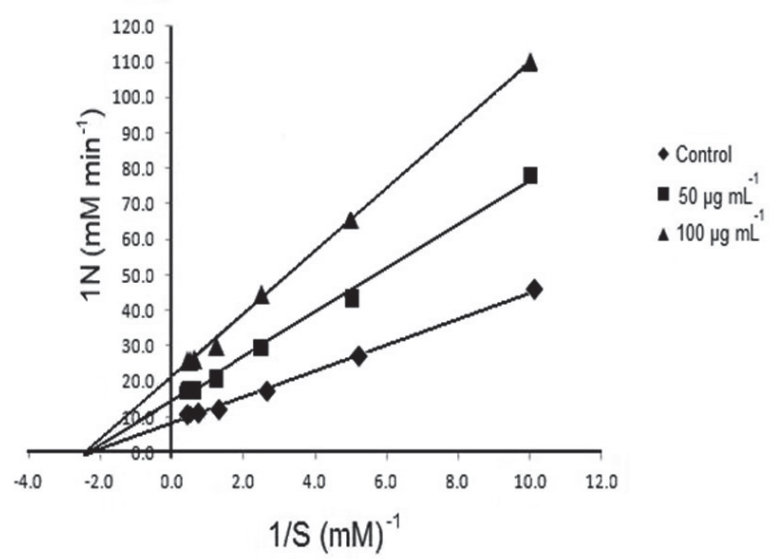

Figure 5. Lineweaver-Burk plot analysis for PPL at two concentrations of the ethanolic extract from Cuphea aequipetala (50 and $100 \mu \mathrm{g} \mathrm{mL}^{-1}$ ), using different triolein concentrations (0.2$2.2 \mathrm{mM})$. 
similar to those reported by Gholamhoseinian et al. (2010) but slight variations in $\mathrm{K}_{\mathrm{m}}$ and $\mathrm{V}_{\max }$ could be caused by the assay buffer ( $\mathrm{pH}$ 9.0) and its composition. Considering the biochemical evidence, four plants exhibited very strong in vitro anti-lipase activity $(>60 \%), S$. erianthum being the most effective. S. erianthum is currently used in Oaxaca State as an oral analgesic to treat stomach ache and as a cutaneous antimicrobial agent. The chemistry of S. erianthum consists of sesquiterpenes as well as high endogenous levels of steroidalalkaloid glycosides, tropane-alkaloids and tannins in the aerial parts (Essien et al., 2012; Maurya et al., 2013). Some strong antilipase activities are apparently associated with pentacyclictriterpene glycosides as is the case with teasaponins, which share an association in chemical structure with S. erianthum glycosides (Birari and Bhutani 2007; Tucci et al., 2010). The results of phytochemical screening support the presence of tannins, terpenes, steroids and saponins which could be involved in those effects (Table II). However, the noncompetitive inhibition by the crude ethanolic extract suggests that many compounds may be involved in the observed biochemical behavior. Despite the aerial parts of this plant having evident anti-lipase properties, the toxic endogenous levels of tropane and Solanum alkaloids (Table II) must be considered before performing in vivo trials (Huang et al., 2009). Further chromatographic isolation of the bioactive molecules and their spectroscopic confirmations are necessary to determine the anti-lipase molecules of S. erianthum. S. microphylla was the second-best anti-lipase source. Phenolic compounds, sesquiterpenes, and 12-methoxycarnosic acid, as well as triterpene aglycones such as oleanolic acid, lupeol and $\beta$-sitosterol are the main constituents of this species (Aydogmuş et al., 2006). Our phytochemical tests confirm the incidence of flavonoids tannins, terpenes, steroids and saponins that could include the latter compounds (Table II). Carnosic acid isolated from Salvia offcinalis exhibits a strong in vitro and in vivo PPL inhibition (Tucci et al., 2010). According to our results a mixed inhibition was observed by the ethanolic extract of S. microphylla. This fact suggests the putative involvement of 12-carnosic acid (as a possible competitive inhibitor) and other compounds such as pentacyclic diterpene glycosides and phenolic compounds as non-competitive inhibitors that bind to the enzyme-substrate complex. Carnosic acid and its derivatives seem to be chemo-taxonomic markers of the Salvia genus. Nevertheless, previous reports on anti-

\section{TABLE II}

Comparative phytochemical screening of the most effective anti-lipase and antioxidant ethanolic extracts

\begin{tabular}{|c|c|c|c|c|c|c|c|}
\hline Plant species & Flavonoids & Tannins/phenols & Terpenes & Steroids & Saponins ${ }^{*}$ & Alkaloids & Cardiac Glycosides \\
\hline Solanum erianthum & + & ++ & $\checkmark$ & $\checkmark$ & ++ & ++ & ++ \\
\hline Salvia microphylla & ++ & ++ & $\checkmark$ & $\checkmark$ & + & - & - \\
\hline Brungmansia suaveolens & + & + & $\checkmark$ & $\checkmark$ & ++ & ++ & - \\
\hline Cuphea aequipetala & ++ & ++ & $\checkmark$ & $\checkmark$ & + & + & - \\
\hline Salmea scandens & + & ++ & $\checkmark$ & - & - & ++ & - \\
\hline Arctostaphylos pungens & ++ & ++ & $\checkmark$ & $\checkmark$ & - & - & - \\
\hline Rhus chondroloma & ++ & ++ & $\checkmark$ & $\checkmark$ & - & + & + \\
\hline Cestrum anagyris & ++ & + & - & $\checkmark$ & + & - & - \\
\hline Phaseolus coccineus & ++ & + & - & $\checkmark$ & + & + & - \\
\hline Chiranthodendron pentadactylon & ++ & ++ & $\checkmark$ & $\checkmark$ & - & - & - \\
\hline Sambucus mexicana & ++ & ++ & - & $\checkmark$ & - & + & + \\
\hline Gnaphalium roseum & ++ & + & - & $\checkmark$ & + & - & - \\
\hline Satureja laevigata & ++ & ++ & $\checkmark$ & $\checkmark$ & + & - & - \\
\hline Lippia alba & ++ & + & $\checkmark$ & $\checkmark$ & + & - & - \\
\hline Crotalaria pumila & ++ & + & $\checkmark$ & $\checkmark$ & + & + & + \\
\hline Marrubium vulgare & ++ & ++ & $\checkmark$ & $\checkmark$ & + & - & - \\
\hline Chyrsanthemum parthenium & ++ & ++ & $\checkmark$ & $\checkmark$ & - & + & - \\
\hline Loeselia mexicana & ++ & ++ & $\checkmark$ & $\checkmark$ & - & + & - \\
\hline Microsechium helleri & ++ & + & $\checkmark$ & $\checkmark$ & ++ & - & - \\
\hline Ipomoea wolcottiana & + & ++ & $\checkmark$ & $\checkmark$ & - & ++ & - \\
\hline Artemisa ludoviciana & ++ & + & $\checkmark$ & $\checkmark$ & - & - & - \\
\hline Physalis philadelphica & ++ & + & $\checkmark$ & $\checkmark$ & - & + & - \\
\hline
\end{tabular}

$+50-400 \mu \mathrm{gFW}^{-1}++\geq 500 \mu \mathrm{g} \mathrm{gFW}^{-1}$; - Undetectable under those conditions. * Triterpene saponins. $\sqrt{ }$ Both steroid aglycones and terpene occurrences were qualitatively determined. 
TABLE III

Effect of the four best alcoholic extracts on the kinetic parameters of PPL

\begin{tabular}{ccccc}
\cline { 2 - 4 } & \multicolumn{2}{c}{$\mathbf{K}_{\mathrm{m}}(\mathrm{mM})$} & \multicolumn{2}{c}{$\mathbf{V}_{\text {max }}\left(\mathrm{mM} \mathrm{min}^{-1}\right)$} \\
\hline Extract concentration & $50 \mu \mathrm{g} \mathrm{mL}^{-1}$ & $100 \mu \mathrm{g} \mathrm{mL}^{-1}$ & $50 \mu \mathrm{gL}^{-1}$ & $100 \mu \mathrm{g} \mathrm{mL}^{-1}$ \\
Without inhibitor & $0.364 \pm 0.012 \S$ & $0.364 \pm 0.012 \S$ & $0.085 \pm 0.0017 \S$ & $0.085 \pm 0.0017 \S$ \\
Solanum erianthum & $0.362 \pm 0.022$ & $0.364 \pm 0.013$ & $0.069 \pm 0.0024$ & $0.055 \pm 0.0019$ \\
Salvia microphylla & $0.465 \pm 0.017$ & $0.567 \pm 0.035$ & $0.066 \pm 0.0035$ & $0.051 \pm 0.0011$ \\
Brugmansia suaveolens & $0.452 \pm 0.034$ & $0.643 \pm 0.014$ & $0.050 \pm 0.0017$ & $0.042 \pm 0.0021$ \\
Cuphea aequipetala & $0.365 \pm 0.014$ & $0.362 \pm 0.019$ & $0.061 \pm 0.0045$ & $0.053 \pm 0.0016$ \\
\hline
\end{tabular}

$\S$ Means with standard deviation from experiments performed in quintuplicate. *Results from saturation curves performed under laboratory conditions without any inhibitor

lipase properties of Salvia rhytidea and Salvia miltiorrhiza suggest that only some Salvia species possess worthwhile levels of efficacy (Gholamhoseinian et al., 2010, Zheng et al., 2010). Geographical location, altitude, soil composition, weather and specific biotic elicitors may be involved in the biosynthesis of terpene and phenolic compounds in these plants. The high abundance of phenolic metabolites (Table II) is probably related to the significant antioxidant activity $\left(\mathrm{IC}_{50}=99.2 \mu \mathrm{g} \mathrm{mL}\right.$ ${ }^{-1}$ ) of S. microphylla. The ethanolic extract of flowers from $B$. suaveolens had a mixed inhibition effect on PPL. This species produces classical tropane alkaloids with medicinal uses whose hyoscine is hydrolyzed by this enzyme under buffering conditions (Henry, 1949). Our phytochemical studies also confirm high endogenous levels of alkaloids and saponins as well as a low level of phenolic compounds in B. suaveolens flowers (Table II). This evidence could support the participation of alkaloids and saponins as the main anti-lipase agents. The mixed inhibitory effect on the kinetics of PPL suggests that some tropane alkaloids could interact with both the active site of the enzyme and the enzyme-substrate complex. According to our results, the fourth most efficient species with anti-lipase activity was C. aequipetala, a native Mexican medicinal plant. The plant is commonly known as "hierba del cancer" and has been traditionally administered for centuries without formal reports of poisoning (Waizel-Bucay et al., 2003). According to previous phytochemical studies the aerial parts contain high endogenous levels of fatty acids, mainly miristic acid (in oil fraction), as well as flavonoids and triterpene glycosides in the alcoholic extracts (Hirsinger, 1980; Waizel-Bucay et al., 2003). Detection of phenolics, terpenes, steroids and saponins in the phytochemical screening confirm the possible incidence and involvement of the latter compounds in the effects here reported (Table II). Considering the results of this study and the chemistry of $C$. aequipetala, the significant antioxidant properties $\left(\mathrm{IC}_{50}=76.5 \mu \mathrm{g} \mathrm{mL} \mathrm{m}^{-1}\right.$ ) should be related to phenolic compounds and the strong noncompetitive inhibition on PPL (Figure 5, Table III) could be associated with triterpene glycosides and steroids. Further experiments are required to verify this hypothesis. Due to $C$. aequipetala demonstrating interesting nutritional properties and containing low levels of alkaloids (Table II), this plant could be considered a good candidate for in vivo trials. Another plant with strong anti-lipase activity is $S$. scandens. Currently this species is being studied by our research group and some of the chemical compounds from the stem bark are being isolated, characterized and quantified by chromatographic and spectroscopic methods (data not shown). Interestingly, the phytochemical screening reveals an alkaloid content that could be linked to the presence of specific alkylamides that contain nitrogen and probably interact with Dragendorff's reagent. $A$. pungens represents another desirable source with anti-lipase and antioxidant properties. This study confirms the previous findings of Slanc et al. (2009) where this Ericaceae showed a similar inhibition degree on PPL. The intrinsic chemistry of $A$. pungens reveals the presence of phenolic compounds such as quercetin, catechins and tannins (Winkelman, 1989) which are strongly involved in both biological activities (Zheng et al., 2010). The general composition here found corresponds to high amounts of flavonoids and related phenolics but also with some steroids (Table II). Further chromatographic separations are required to determine the anti-lipase agents of this plant. $R$. chrondoloma and C. anagyris showed good anti-lipase and acceptable antioxidant activities; nevertheless, their chemistry have been poorly studied (Young, 1979). According to our results $R$. chondroloma showed high levels of flavonoids and tannins as well as terpenes and steroids (Table II). The moderate antioxidant activity of its ethanolic extract is probably linked to the high flavonoid and phenolic content (Table II) whereas the anti-lipase effects could be also associated with the latter compounds but possibly with other metabolites such as steroids. Additionally, R. chondroloma sowed an interesting presence of cardiac glycosides. A similar condition is observed for the case of $C$. anagyris (except for cardiac glycosides and alkaloids). Phaseolus coccineus contains a great variety of flavonoids that could participate in the observed anti-lipase activity (Williams et al., 1995); the general composition of its ethanolic extract sustains this finding (Table II). Chiranthodendron pentadactylon ("Flor de Manita") is one of the most relevant plants in Mexican ethnobotany because of its anti-secretory properties (Velázquez et al., 2012). The anti-lipase effect reported in the present work contributes to the discovery of novel uses for this native plant that are strongly related to its antioxidant catechins and flavonoids (Table II). The ethanolic extract of leaves from Sambucus mexicana showed similar antilipase effects to those of $C$. pentadactylon. High endogenous levels of anthocyanins and other phenolic compounds have been reported in this species (Lee et al., 2007). The general phytochemical composition of those extracts endorses the occurrence of phenolic metabolites, steroids and low levels of alkaloids (Table II) but detailed experimentation is required to 
reveal the anti-lipase agents of S. mexicana. Additionally, the presence of cardiac glycosides was detected in the leaf extracts of this plant; this finding could be considered as novel phytochemical information for the plant (Table II). Gholamhoseinian et al. (2010) reported a moderate anti-lipase activity of Artemisia santolina as we do for A. ludoviciana. This latter plant contains high flavonoid content (Table II) that should be participating in the moderate antioxidant activity reported in this study. The terpene content of A. ludoviciana (Table II) could include small quantities of sesquiterpene lactones that perhaps interact with the active site of PPL. It is known that the lactone moiety of Orlistat plays an important function in the irreversible inhibition of PPL. There is no information about the possible involvement of sesquiterpene lactones on this matter so far. Also, the same authors report the same low anti-lipase activity for Marrubium anisodon as we do for M. vulgare. Although this species showed good phenolic content (Table II) and antioxiadant activity (Table I), its antilipase activity was non-significant compared to other plant extracts. The ethanolic preparations of $M$. vulgare and $C$. parthenium clearly show that high phenolic content is not necessarily connected with relevant anti-lipase activity. Loeselia mexicana, Microsechium helleri, S. laevigata, I. wolcottiana and Physalis philadelphica showed a moderate anti-lipase activity and almost all of them except I. wolcottiana and L. mexicana demonstrated an acceptable antioxidant activity (Table I). Current phytochemical studies in $M$. helleri revealed the presence of many triterpene saponins (Hernández-Carlos et al., 2012), some of them perhaps with anti-lipase properties. Presence and high abundance of saponins in this plant is also demonstrated in our phytochemical screening (Table II). C. pumila is an edible plant used to prepare traditional foods; the high phenolic content of this species (Table II) is strongly linked to its characteristic antioxidant activity (Table I). The presence of cardiac glycosides in the ethanolic extract of $C$. pumila could be a new chemical finding for this plant (Table II).

As a final conclusion, we report on some medicinal plants used in the state of Oaxaca-Mexico that possess noteworthy anti-lipase and antioxidant properties. Some of those plant species might be considered as a cheap herbal therapy for the prevention of high prevalence diseases originated by oxidative stress and obesity. The known chemistry and general composition of some species was considered to explain their respective biological activities. Chemical composition and the correlation of the two biological activities demonstrate that plants with anti-lipase activity are not necessarily good antioxidant agents and vice versa. In addition, this study remarks on the need for performing accurate phytochemical experimentation in less-studied plants in order to identify and isolate their bioactive compounds. Comprehensive analyses of the chemistry and toxic risks of these plants leads us to consider S. microphylla, C. aequipetala and A. pungens as the best medicinal plants with both desired properties.

\section{ACKNOWLEDGEMENTS}

We would like to thank "Programa Integral de Fortalecimiento Institucional 2012 (PIFI-2012)", for financial support, as well as Craig Alexander Hilts for reviewing the manuscript. N.V-R. dedicates the present work to memory of Concepción Ruano López (1912-2013) a great man with an enormous empirical knowledge that will never pass away.

\section{REFERENCES}

AYDOGMUŞ Z, YEŞILYURT V, TOPCU G (2006) Constituents of Salvia microphylla. Nat Prod Res 20:775-781.

BIRARI RB, BHUTANI KK (2007) Pancreatic lipase inhibitors from natural sources: unexplored potential. Drug Discov Today 12: 879-889.

CABALLERO J, CORTÉS L, MARTÍNEZ-ALFARO MA, LIRA-SAADE R (2004) Uso y manejo tradicional de la diversidad vegetal. In: GARCÍAMENDOZA AJ, ORDOÑEZ-DÍAZ MJ, BRIONES-SALAS M (eds). Biodiversidad de Oaxaca. $1^{\text {th }}$ ed. Instituto de Biología Universidad Nacional Autónoma de México. pp: 481-541.

CALDERÓN G, RZEDOWSKI J (2005) Flora fanerogámica del Valle de México. 2da ed. Instituto de Ecología, AC. Patzcuaró Michoacán. pp: 5- 975.

EKANEM AP, WANG M, SIMON D, MORENO A (2007) Antiobesity properties of two African plants (Afromomum meleguetta and Spilathes acmella) by pancreatic lipase inhibition. Phytother Res 21: 1253-1255.

ESSIEN EE, IA OGUNWANDE, SETZER WN, EKUNDAYO O (2012) Chemical composition, antimicrobial, and citotoxity studies on Solanum erianthum and Solanum macranthum essential oils. Pharm Biol 50: 474-480.

GHOLAMHOSEINIAN A, SHAHOUZEHI B, SHARIFI-FAR F (2010) Inhibitory effect of some plant extracts on pancreatic lipase. Int J Pharm 6:18-24.

HENRY TA (1949) The plant alkaloids. 4th edition. The Blakiston Company . London GB. pp: 2-64.

HIRSINGER F (1980) Studies to evaluate the agronomic potential of a new MCT oil plant Cuphea (Lythraceae). Natural variability in taxonomic and agronomic characters in Cuphea species. Ang Bot 54: 157-177.

HUANG S-T, SU Y-J, CHIEN D-K, E-J LI, CHANG W-H (2009) Solanum erianthum intoxication mimicking an acute cerebrovascular disease. Am J Emerg Med 27: 249.e1-249.e2.

HÁUAD-MARROQUÍN L (2010) Manual de fitoterapia. 1th edition. Trillas. Nuevo Léon, México. 39-47pp.

HARBORNE JB (1998) Phytochemical methods: A guide to modern techniques of plant analysis. 3th edition. Chapman and Hall. London, UK. 110-315 pp.

HERNÁNDEZ-CARLOS B, GONZÁLEZ-COLOMA A, OROZCOVALENCIA AU, RAMÍREZ-MARES MV, ANDRÉS-YEVES MF, JOSEPHNATHAN P (2012) Bioactive saponins from Microsechium helleri and Sicyos bulbosus. Phytochemistry 72: 743-751.

LEE J, FINN CE (2007) Anthocyanins and other polyphenolics in American elderberry (Sambucus canadensis) and European elderberry (S. nigra) cultivars. J Sci Food Agric 87: 2665-2675.

MARTÍNEZ M (1979) Catálogo de nombres vulgares y científicos de plantas mexicanas. Fondo de Cultura Económica, México DF. pp:9-1220.

MAURYA A, MANIKA N, VERMA RK, SINGH SC, SRIVASTAVA SK (2013) Simple and reliable methods for the determination of three steroidal glycosides in the eight species of solanum by reversed-phase HPLC coupled with diode array detection. Phytochem Anal 24: 87-92.

NUGROHO AE, MALIK A, PRAMONO S (2013) Total phenolic and flavonoid contents and in vitro antihypertension activity of purified extract of Indonesian cashew leaves (Anacardium occidentale L.). Int Food Res J 20: 299-305.

REUTER S, GUPTA SC, CHATURVED MM, AGGARWAL BB (2010) Oxydative stress, inflamation and cancer: how are they linked?. Free Radic Biol Med 49: 1603-1616.

ROJAS-MARTÍNEZ R, AGUILAR-SALINAS CA, JIMÉNEZ-CORONA A, GÓMEZ-PÉREZ FJ, BARQUERA S, LAZCANO-PONCE E (2012) Prevalence of obesity and metabolic síndrome components in Mexican adults without type 2 diabetes or hypertension. Salud Publica Mex 54: 7-12.

SHAFAGHAT A (2011) Chemical constituents, antimicrobial and antioxidant activity of the hexane extract from root and seed of Levisticum persicum Freyn and Bornm. J Med Plant Res 5: 5127-5131.

SHIHABI ZK, BISHOP C (1971) Simplified turbidimetric assay for lipase activity. Clin Chem 17: 1150-1153.

SLANC P, DOLJAK B, KREFT S, LUNDER M, JANES D, STRUKELJ B (2009) Screening of selected food and medicinal plants extracts for pancreatic lipase inhibition. Phytother Res 23: 874-877.

SOLICH P, SEDLIAKOVÁ V, KARLÍČEK R (1992) Spectrophotometric determination of cardiac glycosides by flow-injection analysis. Anal Chem Acta 269: 199-203.

TUCCI SA, BOYLAND EJ, HALFORD JCG (2010) The role of lipid and carbohydrate digestive enzyme inhibitors in the management of obesity: 
a review of current and emerging therapeutic agents. Diabetes Metab Syndr Obes 3: 125-143.

VELÁZQUEZ C, CORREA-BASURTO J, GARCÍA-HERNÁNDEZ N, BARBOSA E, TESORO-CRUZ E, CALZADA M, CALZADA F (2012) Anti-diarrheal activity of (-)-Epicatechin from Chiranthodendron pentadactylonLarreat: Experimental and computational studies. J Ethnopharmacol 143: 716-719.

VILLA-RUANO N, PACHECO-HERNANDEZ Y, LARA-ZARAGOZA EB, FRANCO-MONSREAL J. (2011) Fitoterapia: alternativa para el control de la obesidad. Elementos 84: 21-25.

VILLA-RUANO N, BETANCOURT JIMÉNEZ MG, LOZOYA-GLORIA E (2009) Biosythesis of uterotonic diterpenes from Montanoa tomentosa zoapatle. J Plant Physiol 166: 1961-1967.

VILLA-RUANO N, PACHECO-HERNÁNDEZ Y, RUBIO-ROSAS E, RUIZGONZÁLEZ N, CRUZ-DURAN R, LOZOYA-GLORIA E, ZURITAVÁSQUEZ G, FRANCO-MONSREAL J (2012) Alkaloid profile, antibacterial and allelopathic activities of Lupinus jaimehintoniana, BL Turner. (Fabaceae). Arch Biol Sci 64: 1065-1071.
WAIZEL-BUCAY J, MARTÍNEZ-PORCAYO GM, VILLARREAL-ORTEGA MA, ALONSO-CORTÉS D, PLIEGO-CASTAÑEDA A (2003) Estudio preliminar etnobotánico, fitoquímico de la actividad citotoxica y antimicrobiana de Cuphea aequipetala Cav. (Lithraceae). Polibotánica 15: 99-108.

WILLIAMS CA, ONYILAGHA JC, HARBORNE JB (1995) Flavonoid profiles in leaves, flowers and stems of forty-nine members of the phaseolinae. Biochem Syst Ecol 23: 655-667.

WINKELMAN M (1989) Ethnobotanical treatments of diabetes in Baja California Norte. Med Anthropol 11: 255-268.

YOUNG DA (1979) Heartwood flavonoids and the infrageneric relationships of Rhus (Anacardiaceae). Amer J Bot 66: 502-510.

ZHENG C-D, DUAN Y-Q, GAO J-M, RUAN Z-G (2010) Screening for antilipase properties of 37 traditional Chinese medicinal herbs. J Chin Med Assoc 73: 319-324. 